\title{
ESCOLA ITINERANTE': UMA HISTÓRIA OCULTADA, FORJADA NO CONTEXTO DA LUTA DE CLASSES NO PARANÁ
}

Marlene Lucia Siebert Sapelli ${ }^{2}$

\section{RESUMO}

A pesquisa aqui apresentada parte do pressuposto de que os processos educativos não são neutros, portanto, definidos a partir de determinantes sociais, políticos, econômicos, religiosos, culturais e outros e, ao estarem inseridos no contexto da sociedade capitalista, obrigatoriamente, carregam a marca de classe de quem os engendra e que é necessário explicitar cada vez mais as experiências contra-hegemônicas de educação. Assim, o objetivo dessa pesquisa é descrever e analisar o processo de criação das escolas itinerantes (EI) no Paraná e como elas representam, nos seus dez primeiros anos (2013-2013), a resistência da parcela da classe trabalhadora que compõe o MST (Movimento dos Trabalhadores Rurais Sem Terra), no referido estado. Foi realizada junto ao Programa de Pós-Graduação em Educação da Universidade Federal de Santa Catarina, em curso de Doutorado, por meio de pesquisa bibliográfica, pesquisa de campo (que envolveu registro fotográfico, entrevistas, participação em atividades) e análise documental. Na primeira parte, apresentamos o contexto que deu origem ao MST no Paraná; a seguir, os processos de ocupação dos espaços, nos quais estão inseridas as nove escolas itinerantes que existem no estado; na terceira parte do texto, explicitamos o conjunto das escolas itinerantes e a situação atual de cada uma e para finalizar analisamos as dificuldades dos sujeitos para produzir a vida nos acampamentos em questão e a situação das referidas escolas.

Palavras-chave: escola itinerante; MST; resistência, Paraná

\section{ESCUELA ITINERANTE: UNA HISTORIA OCULTADA, FORJADA EN EL CONTEXTO DE LA LUCHA DE CLASES EN PARANÁ}

\section{RESUMEN}

La investigación aquí presentada parte del presupuesto de que los procesos educativos no son neutros, por lo tanto, definidos a partir de determinantes sociales, políticos, económicos, religiosos, culturales y otros y, al estar inseridos en el contexto de la sociedad capitalista, obligatoriamente, cargan la marca de clase de quien los engendra y que es necesario aclarar cada vez más las experiencias contrahegemónicas de educación. De este modo, el objetivo de esta investigación es describir y analizar el proceso de creación de las escuelas itinerantes en Paraná y como ellas representan, en sus diez primeros años, la resistencia de la parcela de la clase trabajadora que compone el Movimiento de los Trabajadores Rurales Sin Tierra, en el estado mencionado. Fue realizada junto al Programa de Postgrado en Educación de la Universidad Federal de Santa Catarina, en el curso de Doctorado, por medio de investigación bibliográfica, investigación de campo (que involucra registro fotográfico, entrevistas, participación en actividades) y análisis documental. En la primera parte presentamos el contexto que dio origen al MST en Paraná, a continuación, los procesos de ocupación de los espacios en los cuales están inseridas las nueve escuelas itinerantes que existen en el estado; en la tercera parte del texto explicitamos el conjunto de las escuelas itinerantes y la situación actual de cada una y para finalizar analizamos las dificultades de los sujetos para producir la vida en los campamentos en cuestión y la situación de las escuelas.

Palabras clave: escuela itinerante; MST; resistencia; Paraná. 


\section{Introdução}

O Paraná é um dos estados brasileiros que apresenta, historicamente, altos índices de concentração de terra e processos de resistência e de luta para superar tal estado de coisas. O crescimento das propriedades e a concentração da terra ${ }^{3}$, no estado, aumentaram dos anos 1960 para 1970. Pires (2001) indica que em 1965, existiam mais de 550 mil propriedades rurais no Estado, sendo que os estabelecimentos com menos de 50 hectares, ocupavam 43\% da área agrícola; em 1975, existiam 106 mil propriedades com menos de 50 hectares, que ocupavam menos de 30 por cento da área agrícola. A concentração de terras explicita um processo de desapropriação da classe trabalhadora de um dos seus principais meios de produção, portanto, de separação entre o homem e o objeto de trabalho, e as lutas, que são consequência desse processo, irão ser pautadas, justamente, na busca da superação dessa separação, que no âmbito do capitalismo ganha uma complexidade ainda maior, pois, a propriedade da terra não é suficiente para resolver os problemas da classe trabalhadora que está no campo. Apesar de toda essa tensão, nos anos 1950 e 1960, o regime militar, nos anos 1970, acabou quase silenciando os movimentos dos trabalhadores rurais.

Como resultado direto da mordaça imposta pelos militares que assumiram o poder, os movimentos surgidos antes de 1964 foram literalmente exterminados, tendo o mesmo destino os movimentos que tentaram se estruturar em represália às feridas abertas pelas transformações que mal haviam começado no campo. A pressão camponesa desaparece, sem que isso, no entanto, significasse o desaparecimento de suas bandeiras de luta, o que quer dizer que pelo menos no momento da luta havia desaparecido na prática, mas não no seu espírito, que permaneceria durante algum tempo em estado latente para ressurgir logo que a mordaça fosse afrouxada (SERRA, 1991, p. 292)

$\mathrm{Na}$ segunda metade dos anos 1970, houve mudanças no contexto brasileiro: a abertura política anunciada favoreceu a rearticulação do movimento dos trabalhadores rurais; uma ala da igreja, orientada pela Teologia da Libertação ${ }^{4}$, passou a defender os pobres e marginalizados; a expropriação e a expulsão desses trabalhadores fizeram aumentar os focos de tensão social; houve a construção de várias barragens que levou à expulsão de grandes contingentes desses trabalhadores e foram fortalecidas as discussões sobre Reforma Agrária (SERRA, 1991).

Estava em andamento, um processo que já apresentava o embrião do nascimento do MST. Sabemos que ocorreram ações em outros estados, como por exemplo, no Rio Grande do Sul, que também motivaram o nascimento do MST, como é o caso da criação do MASTER (Movimento de Agricultores Sem Terra), que organizou entre 1960 e 1962 mais de vinte e seis acampamentos ${ }^{5}$ naquele estado. Outro exemplo, foi o conflito entre índios e posseiros, em 1979, na Reserva de Nonoai e, em 1981, na Encruzilhada Natalino, houve um acampamento na beira da estrada, com 600 famílias, no município de Ronda Alta, no mesmo estado (PIRES, 2001). No Paraná, um dos fatores mais importantes para a criação do MST e de outros movimentos foi a construção de usinas hidrelétricas. Segundo Pires (2001) e Serra (1991), a primeira experiência foi a de Salto Santiago, concluída em 1979. Os municípios atingidos foram Laranjeiras do Sul, Chopinzinho, Mangueirinha e Coronel Vivida. Naquele momento, não havia organização suficiente dos camponeses para protestar e se contrapor às decisões tomadas, especialmente no que dizia respeito às indenizações e isso serviu de motivo, além de outros, para uma maior organização dos trabalhadores do 
campo, portanto, a mesma nasceu das necessidades produzidas na materialidade e não da vontade dos trabalhadores.

Nos anos 1970, foi construída a Usina Hidrelétrica de Itaipu que provocou a desapropriação de mais de sete mil famílias, que foram retiradas do canteiro de obras a partir de 1978. Segundo Serra (1991), foram poucos que aceitaram os valores propostos para as indenizações.

Para ajudar a resolver a situação, em 1980, foi criado o Movimento Justiça e Terra (MORISSAWA, 2001). De acordo com Mazzarollo (2003), esse Movimento defendia justiça na avaliação do valor das propriedades e terra para os desalojados. $\mathrm{O}$ autor afirma que nos textos do Movimento Justiça e Terra havia alertas sobre a necessidade de organização popular que precisava se antecipar às obras similares, que ainda viriam.

Serra (1991) conta que a pressão organizada por esse Movimento foi forte na época. Houve acampamentos organizados em frente ao escritório da Itaipu Binacional (Santa Helena) durante 17 dias, em 1980 e, durante 57 dias, em 1981. O autor afirma que o acampamento representava uma forma do trabalhador rural fazer sua greve, protestando objetivamente para obter do poder público, soluções para seu drama coletivo. Com essa pressão, a Itaipu Binacional acabou atendendo grande parte das reivindicações ${ }^{6}$.

Desse Movimento todo acabou nascendo outro, o Mastro (Movimento dos Agricultores do Oeste do Paraná) que, nas últimas etapas de lutas dos desapropriados da Itaipu, enfatizava a necessidade de indenização também aos que não eram proprietários, mas trabalhavam na terra. Esses processos traziam o embrião para o nascimento do MST. Entre 1970 e 1980, várias lutas pelas terras se davam em São Paulo, Santa Catarina, Paraná, Rio Grande do Sul e Mato Grosso do Sul. Sentia-se a necessidade de agregar esforços.

Não podemos deixar de explicitar a origem "religiosa" do MST. Pires (2001) nos dá elementos para isso. Stédile, ao ser entrevistado pelo autor, em 1997, afirmou que

O Movimento dos Trabalhadores Rurais Sem-Terra é 'filhote da igreja'. A Igreja, através da CPT, é fundamental no nosso processo de organização. Apesar de ter desenvolvido um papel importante na etapa final da ditadura, a igreja refluiu no final dos anos 1980 e início dos 1990. Porém, de uns anos para cá, nós percebemos que tanto a igreja católica quanto a luterana, retomaram um trabalho pastoral de base com um cunho progressista (PIRES, 2001, p. 65).

João Pedro Stédile, que é um dos líderes do MST, reconhece o papel da igreja, principalmente da $\mathrm{CPT}^{7}$ (Comissão Pastoral da Terra), na organização inicial do Movimento, mas indica, segundo Pires (2001), que a mesma igreja que apoiou o Movimento impôs limites quando o mesmo definiu e praticou ações que extrapolaram a política social católica. $\mathrm{O}$ autor analisou vários documentos da igreja e salienta que os

[...] postulados da Teologia da Libertação forneceram a justificativa teórica para atuação das pastorais no meio popular, principalmente da CPT, em especial nos pressupostos formulados a partir de 1968 - ano do encontro de Medellín - nascidos da prática de alguns cristãos em movimentos sociais da América Latina (PIRES, 2001, p. 67).

A igreja, independentemente da religião à qual se vincula, articulou-se aos movimentos sociais de luta pela terra por uma pequena, quase insignificante parcela dos seus dirigentes. Sua natureza, construída nas relações, mas camuflada por ideais transcendentes a elas, mais contribui para a manutenção do que para a ruptura com o atual estado de coisas, pela via do conformismo e do enaltecimento da magnitude do sofrimento 
humano na busca de recompensas futuras, fora dessa materialidade, portanto, indicando as soluções dos problemas sem conflitos, para um tempo e espaço que podem não existir, ficando isenta de se confrontar com uma ou outra classe social, pregando, inclusive, uma necessária harmonia entre elas.

Os anos 1980, para o $\mathrm{MST}^{8}$, foram marcados por encontros, seminários, cartas e o Paraná foi palco de alguns deles. O Primeiro Encontro de Agricultores Sem Terra do Sul, foi justamente, em Medianeira, em 1982, no qual estavam presentes representantes de cinco estados brasileiros: São Paulo, Santa Catarina, Rio Grande do Sul, Paraná e Mato Grosso do Sul. Em 1984, foi realizado em Cascavel, o I Encontro Nacional dos Trabalhadores Rurais Sem Terra, no qual nasceu oficialmente o MST e estavam presentes trabalhadores de doze estados brasileiros. Em 1985, realizou-se em Curitiba, o I Encontro Nacional dos Sem Terra com a participação de 1600 delegados de todo o Brasil (MORISSAWA, 2001).

No Paraná, como em outros estados, são forjados processos educativos em espaços/tempos ocupados pelo Movimento dos Trabalhadores Rurais Sem Terra, pois a luta pela terra agrega outras tantas lutas, como no caso, por educação. Temos por objetivo, apresentar, a partir desse entendimento inicial, como foi o processo de criação das escolas itinerantes no Paraná e como elas representam nos seus dez primeiros anos a resistência da parcela da classe trabalhadora que compõe o Movimento, no referido estado. Descrever e analisar os fatos históricos desse período também revela que essas escolas foram forjadas num processo de luta pela terra, de conflitos, de enfrentamentos, tendo um projeto estratégico bem definido como orientador, tanto da luta pela terra, como do esforço de construção da sua proposta pedagógica.

\section{A criação e os primeiros anos das escolas itinerantes no Paraná}

As primeiras escolas itinerantes foram criadas no Paraná, em 2003 e 2004, num contexto latente de ocupações, consequência também da expectativa no governo Lula em relação à consolidação de uma ampla Reforma Agrária. Entre 2003 e 2004, houve no Paraná 121 conflitos, envolvendo 18.578 famílias (CPT, 2006). Só em 2004, ocorreram no estado, 45 ocupações que envolveram 5.740 famílias de dez diferentes movimentos de luta pela terra. Uma dessas ocupações foi em Cascavel, no Complexo Agrícola Cajati (onde está situada a Escola Itinerante Zumbi dos Palmares e onde se encontrava, até 2012, a Escola Itinerante Oziel Alves), da família Festugato, propriedade com 30.000 hectares, no dia 01 de agosto de 2004, por 900 famílias, que vieram do Acampamento Dorcelina Folador (ocupação feita em 1999), no mesmo complexo, e de outras localidades (TAKAU JUNIOR, 2009). Outra ocupação foi em Diamante do Oeste, onde foi organizado pela Comunidade Roselito um acampamento provisório, que reuniu em torno de 900 famílias, que no dia 31 de julho ocuparam a Fazenda Boito (onde está situada a Escola Itinerante Sementes do Amanhã), em Matelândia, com 380 alqueires. Nesse mesmo dia foi ocupada, por 400 famílias, a Fazenda Santa Filomena (Onde está situada a Escola Itinerante Carlos Marighela), com aproximadamente 800 alqueires (havia sido declarada, em 1997, como de interesse para fins da Reforma Agrária). Na ocupação deste local, houve troca de tiros e sete trabalhadores Sem Terra ficaram gravemente feridos. Entre eles estava Elias Gonçalves de Meura, de 20 anos, que acabou falecendo. O Acampamento recebeu o seu nome (MST, 2008 a). Lembremos que foi nesse contexto de luta que, em 2003, foram criadas as escolas itinerantes no Paraná.

Em 2005, quarenta famílias integrantes do MST, ocuparam uma área de preservação ambiental de 250 hectares, em Paula Freitas (onde atualmente está a situada a Escola Itinerante Paulo Freire), com $80 \%$ de mata araucária, que pertencia ao extinto Banestado 
(MANOEL, 2005), entrando em conflito, em 2006, com José Luiz Estácio e outros trabalhadores, acusados pelo Movimento de explorarem, ilegalmente, a madeira que havia na área e de terem atirado contra os barracos dos acampados (SEM-TERRA, 2006).

Um grupo de famílias acampou, em 2006, às margens da Fazenda Itapema, em Jacarezinho (onde está situada a Escola Itinerante Valmir Motta de Oliveira), no norte do Paraná e em 2008, cerca de 250 famílias ocuparam a fazenda que tem uma área de 793 hectares e era de propriedade de Roberto Barros. A fazenda já havia sido desapropriada pelo INCRA (Instituto Nacional de Colonização e Reforma Agrária), cumprindo decreto presidencial de 18 de janeiro de 2008, para fins de Reforma Agrária (MST, 2008 b).

De 1988 a $2006^{9}$, no Paraná, foram 624 ocupações por 79.766 famílias, sendo 149 ocupações por 27.010 famílias no período de 2000 a 2006. De 1979 a 2006, no Paraná, foram criados 300 assentamentos para 19.066 famílias, em uma área de 402.052 hectares (DATALUTA, 2006).

Em 01/09/2007 ${ }^{10}$, foi ocupada a Fazenda Mestiça, em Rio Branco do Ivaí (onde está situada a Escola Itinerante Construtores do Futuro), norte do Paraná. A ocupação foi feita com quinhentas famílias, quando na fazenda moravam doze famílias. Segundo depoimento ${ }^{11}$ de duas lideranças do acampamento $1^{\circ}$ De Setembro, houve uma tentativa de despejo em 11/10/2007, quando havia 230 famílias e um despejo em 18/12/2007, no qual os policiais destruíram os barracos, quando as famílias foram para o Acampamento Maila Sabrina, em Ortigueira, mas em 29/12/2007, as famílias retornaram, reconstruíram os barracos e começaram a colheita do feijão que haviam deixado para trás. Depois disso, receberam várias ameaças.

Em novembro de 2008, aproximadamente 2000 integrantes do MST ocuparam a Fazenda Variante (onde está situada a Escola Itinerante Herdeiros da Luta de Porecatu), com 1326 hectares, do Grupo Atalla, acusado de ter na fazenda trabalho escravo (CRISTO, 2008). De acordo com o depoimento ${ }^{12}$ de uma das lideranças do acampamento, a ocupação foi feita sem confronto, mas por um longo período houve tensão entre os integrantes do Movimento e a empresa de segurança, contratada pelo Grupo e a própria polícia civil. Segundo ele, o Grupo tem dívidas com a União, cometeu crime ambiental e tinha trabalho escravo na fazenda (em 2008 foram resgatados dezessete trabalhadores em área do Grupo em condições degradantes de trabalho).

Em 2009, foi feita a segunda ocupação da Fazenda Guairacá, em Londrina, onde está situada a EI Maria Aparecida Rosignol Franciosi.

Apesar desse processo intenso de lutas, de ocupações no Paraná, o Movimento vive hoje um momento de refluxo, de dificuldades em manter as ocupações. Houve diminuição no número de moradores da maioria dos acampamentos. O processo de Reforma Agrária tem sido conduzido de forma muito lenta e pouco abrangente e isso tem provocado o desânimo das famílias que, em alguns casos, não conseguem nem produzir para sobreviver.

Segundo um dos coordenadores do Coletivo Estadual de Educação do Paraná, em 2011, existiam no estado 64 acampamentos, sendo que em dez deles havia escolas (em 2014, em nove apenas); 286 assentamentos com, aproximadamente, 18.770 famílias assentadas. Além disso, eram naquele ano 21 colégios estaduais e em torno de 105 escolas municipais em Assentamentos; quatro centros de Educação em Agroecologia e duas Casas Familiares Rurais, ligadas ao MST, no Paraná.

Nesse processo intenso de luta pela terra, o MST entendeu que era necessário conciliar os objetivos específicos, a produção e a educação. Assim, além da luta pela terra, o MST agrega outras lutas. Uma delas é o acesso dos militantes à educação formal e não formal. Nesse sentido, o Movimento entende que é necessário no processo de educação formal: alfabetização de jovens e adultos; construção de salas de aulas nos assentamentos, próximo deles e nos acampamentos; escola pública gratuita; cursos de nível superior; valorização dos professores do meio rural; capacitação e formação profissional dos 
trabalhadores; formação continuada para professores das escolas de áreas de Reforma Agrária; diretriz nacional para implantação/legalização das escolas dos acampamentos.

Já nos anos 1980, o Movimento expressava preocupação com a educação e indicava que o estudo era importante "para buscar soluções, achar o rumo - a direção; não ser iludido, interferir na realidade" [...] "com o objetivo de criar uma nova sociedade socialista sob o comando dos trabalhadores" (MST, 1987 a, p. 16). E mais: que "a força da enxada precisa ser combinada com a sabedoria política, com competência técnica e científica" (MST, 1987 b, p. 16). Considerava que era preciso juntar o fazer e o saber, pois, para dominar, a burguesia havia separado os dois (MST, 1988).

O Movimento entendia que

a escola é um mecanismo de transmissão do saber acumulado pela sociedade ao longo da história, bem como da formação da consciência dos indivíduos. Numa sociedade de classes a escola funciona também como legitimadora da dominação; os conteúdos e os métodos, estão direcionados para a manutenção da ordem existente (MST, 1989 a, p.4).

Naquela época, o Movimento reconhecia que não possuía organização suficiente para desenvolver o setor de educação em toda sua potencialidade (MST, 1989 a). Segundo depoimento $^{13}$ de um dos coordenadores do Coletivo Estadual de Educação/PR, o Movimento conta com o Coletivo Nacional e com Coletivo Estadual de Educação. O Coletivo Nacional é composto por representantes dos Coletivos Estaduais e tem como objetivos lutar por políticas públicas para que o Estado garanta o direito a escolas e à educação (no sentido mais amplo) nos acampamentos e assentamentos; acumular, registrar e refletir sobre as experiências acumuladas; orientar os coletivos estaduais; formar militantes. Mais recentemente, onde há Escolas Itinerantes, o Coletivo Estadual tem assumido a responsabilidade de mediar a relação entre as Escolas Itinerantes e as secretarias estaduais de educação, para isso tem feito reuniões técnicas. Também tem organizado a formação continuada dos educadores das EI, mas há dificuldades, pois, os recursos repassados são insuficientes.

Mesmo com a dificuldade inicial, o Movimento já estava se organizando e anunciava pelo menos três princípios da sua proposta (MST, 1989 b): a necessidade de se estabelecer relação entre processo educativo e organizativo, buscando construir "educação na ação organizada e para a ação organizada" (Idem, p.4); a formação integral dos sujeitos; e a unidade entre teoria e prática, propondo a prática social como ponto de partida e considerando três tarefas em relação ao saber universal, a saber: apropriar-se dele, fazer a crítica a ele e produzir novo saber.

Diante do levantamento dessas afirmações nos jornais do MST dos anos 1980, percebemos várias questões. Uma delas é sempre a preocupação em vincular o processo educativo ao projeto social, indicando-a como instrumento, sem desconsiderar seu caráter contraditório. Também a preocupação com as várias dimensões do desenvolvimento humano, indicando os aspectos valorativos, políticos, técnicos, científicos, entendendo-os como indissociáveis para o enfrentamento das questões objetivas postas pela luta. $\mathrm{O}$ Movimento também indica não abrir mão nem dos processos formais, nem dos processos não formais para formação dos militantes. Também percebemos, o embrião da proposta atual do Movimento, especialmente no que diz respeito aos princípios filosóficos e pedagógicos adotados.

Nesse mesmo período, era forte a presença de Paulo Freire na sustentação da concepção de educação do Movimento. No Jornal Sem Terra, de março de 1989, foi publicada uma entrevista do educador que afirmava que "A educação não é a alavanca da transformação social, mas transformação social implica educação. Ela não é a chave, mas 
faz parte dos componentes da transformação revolucionária" [...] "a educação é sempre um ato político" [...] "A educação desenvolve os trabalhadores, faz sua força crescer" (MST, 1989 a, p. 16).

Desde o início, o MST se preocupou em realizar no mesmo processo de luta pela terra, a luta pela educação. As primeiras experiências de criar escolas em acampamentos aconteceram antes mesmo da criação oficial do MST, em 1984, pois em 1982, segundo Camini (2009), na Encruzilhada Natalino houve um acampamento à beira da estrada, com 600 famílias, onde se construiu a primeira escola em acampamento, que foi legalizada em abril de 1984, no Assentamento Nova Ronda Alta. Foi essa a primeira experiência de escola em acampamento no Brasil. A segunda foi na Fazenda Annoni, município de Sarandi, RS, em 1985. Apesar de mostrar que essas foram as duas primeiras experiências, nenhuma delas foi legalizada em acampamento. Somente em 1996, segundo a autora, é que o Conselho Estadual de Educação do Rio Grande do Sul, por meio do Parecer 1313/96, com base no artigo da Lei Federal 5692/71, aprovou o funcionamento da escola itinerante como 'experiência pedagógica', por dois anos. Essa experiência foi prorrogada por duas vezes pelas Resoluções 237/98 e 247/99 (CAMINI, 2009). Mesmo sendo legalizada, a escola itinerante sofreu pressões no Rio Grande do Sul, especialmente durante o governo de Yeda Crusius, que levou ao fechamento das mesmas, em 2009 (WEISSHEIMER, 2009). Nos arquivos do MST/PR encontramos vários documentos (Convênios, Relatórios, Formulários e outros) produzidos na experiência de lá e que serviam de referência para os encaminhamentos no Paraná.

Isso impulsionou a luta em outros estados. No Paraná, a criação das escolas itinerantes ${ }^{14}$, em 2003, foi inspirada, além da experiência do Rio Grande do Sul, na experiência feita em 1999 (PR), quando foi instalado um acampamento em frente ao Palácio do Iguaçu, em Curitiba/PR, em protesto às políticas do Governo Jaime Lerner, em relação à Reforma Agrária e lá foi organizada uma escola que funcionou durante 14 dias. Esta experiência foi batizada de Escola Itinerante (MST, 2008 b). Além disso, houve experiências em escolas em acampamento, antes mesmo da aprovação pelo Conselho Estadual de Educação, mas que eram, em geral, extensão de outra escola pública. Exemplo disso, foi a escola que funcionou, em 1996, no Acampamento do Buraco, no processo de ocupação da Fazenda Pinhal Ralo, segundo depoimento ${ }^{15}$ de um dos coordenadores do Coletivo Estadual de Educação/PR. Uma das experiências decisivas para a instituição das escolas itinerantes foi a realizada no Acampamento $1^{\circ}$. de Maio, em 2003, com a criação da Escola Itinerante Paulo Freire. Podemos considerar essa experiência o marco do processo de criação dessas escolas no Paraná.

Em geral, as crianças eram transportadas dos acampamentos para as escolas dos distritos ou municípios e lá, muitas vezes, eram discriminadas por serem do acampamento do MST, e até por cheirarem fumaça. O conteúdo trabalhado nas escolas para onde iam, também não atendia aos objetivos do Movimento (MST, 2008 b). Assim, o MST se organizou para criar, no Paraná, as escolas de acampamento. Segundo depoimento de um dos coordenadores do Coletivo Estadual de Educação/PR, Alessandro Mariano, também foram motivos que levaram à criação das escolas: o avanço alcançado nas Conferências Nacionais por uma Educação no/do Campo sobre o entendimento do direito à educação; o número de pessoas que viviam em itinerância e a possibilidade do Movimento poder interferir, tomar decisões em relação ao processo educativo destinado aos integrantes do Movimento. Maria Izabel Grein, também da coordenação do Coletivo Estadual de Educação do Movimento, relata ${ }^{16}$ que, quando Luís Inácio Lula da Silva foi eleito, em 2002, o povo acreditou que a Reforma Agrária aconteceria de fato. Isso trouxe mais gente para os acampamentos, portanto, mais crianças que precisavam de escolas. As escolas próximas aos acampamentos não tinham vagas suficientes para receber as crianças. Conta ela, por exemplo, que do Acampamento Dorcelina Folador (Cascavel/PR) saiam, 
diariamente, três ônibus lotados de crianças para escolas em São João e Rio do Salto. O Movimento pediu uma audiência com o governador para expor a situação. $\mathrm{O}$ governo Requião entendeu a necessidade de tais escolas e, em seguida, foram feitas onze reuniões com diferentes departamentos da SEED/PR (Secretaria de Estado da Educação/Paraná) para definir a criação das escolas itinerantes. A questão não se resolveu na Secretaria e foi encaminhada ao CEE/PR (Conselho Estadual de Educação/Paraná). O processo contou com o apoio de Sonia Fatima Schwendler, que havia assumido a coordenação da Educação do Campo (2003), na SEED/PR, que mediou o diálogo com os conselheiros. Maria Izabel Grein conta que os primeiros problemas, após criadas as escolas itinerantes, estavam relacionados às matrículas dos educandos, pois, o sistema de informática da SEED/PR não previa turmas de Educação Infantil e anos iniciais do Ensino fundamental.

Conforme Camini (2009), no processo de criação oficial das EI do Paraná, uma das primeiras tarefas foi conhecer a experiência do Rio Grande do Sul. Para isso a equipe do Paraná visitou o Instituto Josué de Castro (Veranópolis/RS) e foi conhecer a Escola base Escola Estadual de Ensino Fundamental e Médio Nova Sociedade no Assentamento Itapuí, município de Nova Santa Rita. Assim, por meio do Parecer 1012, em 8 de dezembro de 2003 e da Resolução 614, de 17 de fevereiro de 2004, da SEED/PR, o CEE aprovou o funcionamento das escolas itinerantes no Paraná, como 'experiência pedagógica', por dois anos e, em 2005, sob o Parecer 735/05, renovada por mais 3 anos. Em 2008, a SEED apresentou um relatório sobre a experiência que foi aprovado pelo CEE/PR.

A escola itinerante foi criada para "atender as crianças, adolescentes, jovens e adultos em situação de itinerância, enquanto estão acampados lutando pela desapropriação das terras improdutivas e implantação do assentamento" (MST, 2008 b, p. 88). Seus objetivos eram/são: ser uma escola do Movimento, vinculada e comprometida com a luta pela Reforma Agrária e da classe trabalhadora; formar para a atualidade; promover uma educação voltada para a formação omnilateral; garantir apropriação dos conhecimentos produzidos socialmente; democratizar as relações na escola; privilegiar na metodologia de ensino, processos de cooperação, trabalho e participação; promover integração entre escola e comunidade (MST, s/d, s/p).

Num texto, no qual se apresenta uma avaliação dos quatorze primeiros anos de Escola Itinerante no Brasil, Camini e Ribeiro (2011) evidenciam que a mesma não é "uma escolha, mas um imperativo ao povo sem terra, destituído de direitos essenciais à vida humana" (p. 139) e que a mesma não está isenta de contradições, que representa um espaço de contraposição, de resistência, tendo potencialidade para provocar mudanças e que acompanha os processos de luta dos trabalhadores.

Para custear as despesas das escolas itinerantes, com pessoal, foi celebrado um convênio $^{17}$ entre o governo do Paraná e a Associação de Cooperação Agrícola e Reforma Agrária do Paraná (ACAP), que é pessoa jurídica de direito privado. Os recursos repassados a ela foram destinados especificamente para pagar salários, encargos sociais, $13^{\circ}$. Salário, terço constitucional e verbas rescisórias, sendo a liberação desses recursos feita em parcelas mensais. A Associação tinha que apresentar relatórios semestrais e finais contendo número de educandos, séries, educadores e coordenadores com grau de formação, ações desenvolvidas, análise e discussão do processo e resultados dos trabalhos desenvolvidos nas EI. Além desse Convênio, o governo do estado do Paraná compra e repassa às escolas: livros, materiais para cozinha, folhas de madeirite, folhas de amianto, eletrodomésticos, móveis, caixa d'água, TV, DVD. Como a estrutura da escola é simples ela custa muito pouco aos cofres públicos. Mesmo assim, o repasse de materiais é insuficiente, por isso, a maioria das EI se encontra em situação precária. Nos arquivos da Secretaria do MST, em Curitiba, encontramos muitos documentos encaminhados a órgãos do governo, solicitando materiais. Muitos desses pedidos não foram atendidos e uma das justificativas para isso, era a ilegalidade da situação de ocupação. Segundo depoimento ${ }^{18}$ 
de um dos coordenadores do Coletivo Estadual de Educação do MST/PR (já citado anteriormente), a estrutura precária da escola torna cômoda a situação do governo, pois é uma escola barata, mas nem essa estrutura o governo tem mantido adequadamente. Segundo ele, a tendência é que o governo se desobrigue à medida que a comunidade o faz e essa precariedade tem comprometido a qualidade do trabalho realizado nas escolas.

Em 2004, eram 6 escolas itinerantes; em 2005, eram 9; de 2006 a 2009 eram 11 escolas (MST, 2008 b). Em 2010 e 2011 eram 10, em 2012 e 2013 eram 9 escolas. Nesse período houve um decréscimo no número de educandos, que está relacionado à diminuição do número de moradores nos acampamentos.

Todas as escolas itinerantes, mesmo as que atendem a Educação Infantil e os anos iniciais do Ensino Fundamental, fazem parte da rede estadual, dada sua natureza de itinerância, podendo por isso mudar de município. Justamente por essa natureza itinerante, precisam estar vinculadas a uma escola-base que foi designada para acompanhar e dar suporte legal e pedagógico a elas. Todas as escolas itinerantes têm (a partir de 2013) como escola-base, o Colégio Estadual Iraci Salete Strozak (situado no Assentamento Marcos Freire, em Rio Bonito do Iguaçu/PR). É na escola-base que ficam arquivados os documentos dos educandos das escolas itinerantes e é ela quem faz o cadastramento e expede documentos dos educandos e dá suporte pedagógico às EI. O Colégio foi escolhido para ser escola-base das itinerantes por causa da proposta que desenvolve e por estar localizado num dos maiores assentamentos da América Latina. Isso foi regulamentado pelo Parecer 1.012/2003 do Conselho Estadual de Educação do Paraná, ratificado na Resolução $614 / 2004$ que diz o seguinte:

Art $1^{\circ}$. - Autorizar a implantação da Escola Itinerante nos acampamentos do Movimento dos Trabalhadores Rurais Sem Terra, que terá como mantenedor o Governo do Estado do Paraná e como escola base o Colégio Estadual Iraci Salete Strozak - Ensino Fundamental e Médio, localizado no Assentamento Marcos Freire, no município de Rio Bonito do Iguaçu, no NRE de Laranjeiras do Sul, a partir do ano letivo de 2004, com a oferta de Educação Infantil, Ensino Fundamental e Médio, Educação Profissional e Educação de Jovens e Adultos.

$\S 1^{\circ}$. - Para garantir a estrutura e o funcionamento da Proposta Pedagógica da Escola Itinerante, a Unidade Escolar citada no artigo servirá como Escola Base e será responsável pelo registro, guarda e expedição da documentação escolar do aluno assim como pelo suporte legal e pedagógico.

No quadro a seguir, apresentamos todas as escolas itinerantes ${ }^{19}$ criadas em acampamentos, no Paraná, de 2003 em diante e a situação em que se encontravam em 2013. Nesse período foram criadas dezessete escolas itinerantes, destas, três passaram a funcionar em assentamentos, cinco cessaram suas atividades e nove continuavam ativas.

Quadro 1 - Escolas Itinerantes do Paraná, criadas a partir de 2003 e situação em 2013

\begin{tabular}{|l|l|l|l|l|}
\hline \multicolumn{1}{|c|}{ Escola } & \multicolumn{1}{|c|}{$\begin{array}{c}\text { Acampamento/ } \\
\text { Município }\end{array}$} & \multicolumn{1}{c|}{$\begin{array}{c}\text { Data da } \\
\text { ocupação }\end{array}$} & $\begin{array}{c}\text { Data de início } \\
\text { da escola }\end{array}$ & \multicolumn{1}{c|}{$\begin{array}{c}\text { Situação em 2013 ou } \\
\text { período anterior }\end{array}$} \\
\hline $\begin{array}{l}\text { E. I. Antonio } \\
\text { Tavares }\end{array}$ & $\begin{array}{l}2^{\text {a }} \text {. Conquista/ } \\
\text { Espigão Alto do } \\
\text { Iguaçu }\end{array}$ & $\begin{array}{l}\text { Anterior a } \\
2003\end{array}$ & Março de 2003 & $\begin{array}{l}\text { Encerrou suas atividades em } \\
\text { 2006 por causa de despejo. }\end{array}$ \\
\hline $\begin{array}{l}\text { E. I. Anton } \\
\text { Makarenko }\end{array}$ & $\begin{array}{l}\text { Companheira Roseli } \\
\text { Nunes/ Amaporã }\end{array}$ & $27 / 07 / 2005$ & $\begin{array}{l}\text { Outubro de } \\
2005\end{array}$ & $\begin{array}{l}\text { Em 2008 passou a ser escola } \\
\text { de Assentamento }\end{array}$ \\
\hline
\end{tabular}




\begin{tabular}{|c|c|c|c|c|}
\hline $\begin{array}{l}\text { E. I. Ernesto } \\
\text { Che Guevara }\end{array}$ & $\begin{array}{l}\text { Quilombo dos } \\
\text { Palmares/ Jardim } \\
\text { Olinda }^{20} \\
\text { Março 2007 (Fazenda } \\
\text { Videira) } \\
\text { Em 6/3/2008 foi para o } \\
\text { Acampamento Oito de } \\
\text { Março/Guairacá }\end{array}$ & $\begin{array}{l}2003 \text { (no } \\
\text { Quilombo dos } \\
\text { Palmares) }\end{array}$ & 2004 & $\begin{array}{l}\text { Encerrou suas atividades em } \\
2009 \text {. }\end{array}$ \\
\hline $\begin{array}{l}\text { E. I. Novos } \\
\text { Caminhos do } \\
\text { Campo }\end{array}$ & $\begin{array}{l}4 \text { de setembro/ Céu } \\
\text { Azul }\end{array}$ & $04 / 07 / 2006$ & $\begin{array}{l}\text { Fevereiro de } \\
2007\end{array}$ & $\begin{array}{l}\text { Várias famílias foram } \\
\text { assentadas e a escola encerrou } \\
\text { suas atividades em } 2008\end{array}$ \\
\hline E. I. Terra Livre & $\begin{array}{l}\text { Terra Livre/ } \\
\text { Santa Tereza do } \\
\text { Oeste/Cascavel }\end{array}$ & $14 / 03 / 2006$ & Março de 2006 & $\begin{array}{l}\text { Em } 2008 \text { foi despejada e } \\
\text { encerrou suas atividades }\end{array}$ \\
\hline $\begin{array}{l}\text { E. I. Chico } \\
\text { Mendes }\end{array}$ & $\begin{array}{l}\text { Acampamento José } \\
\text { Abílio dos Santos/ } \\
\text { Quedas do Iguaçu }\end{array}$ & $10 / 05 / 1999$ & $30 / 10 / 2003$ & $\begin{array}{l}\text { Escola do assentamento Celso } \\
\text { Furtado a partir de } 2007 \text {. }\end{array}$ \\
\hline $\begin{array}{l}\text { E. I Olga } \\
\text { Benário }\end{array}$ & $\begin{array}{l}\text { Acampamento Dez de } \\
\text { Maio/ } \\
\text { Quedas do Iguaçu }\end{array}$ & 10/05/1999 & $16 / 02 / 2004$ & $\begin{array}{l}\text { Escola do assentamento Celso } \\
\text { Furtado a partir de } 2007 \text {. }\end{array}$ \\
\hline $\begin{array}{l}\text { Escola } \\
\text { Itinerante Oziel } \\
\text { Alves }\end{array}$ & $\begin{array}{l}\text { Casa Nova/ } \\
\text { Cascavel }\end{array}$ & 1999 & 2007 & $\begin{array}{l}\text { Incorporada à EI Zumbi dos } \\
\text { Palmares em 2012, passando a } \\
\text { funcionar no Pré- } \\
\text { Assentamento Valmir Motta }\end{array}$ \\
\hline $\begin{array}{l}\text { Escola } \\
\text { Itinerante } \\
\text { Zumbi dos } \\
\text { Palmares }\end{array}$ & $\begin{array}{l}\text { Criada no } \\
\text { Acampamento } \\
\text { Dorcelina Folador } \\
\text { (fazenda Cajati) e } \\
\text { depois levada ao } \\
\text { Acampamento } 1^{\circ} \text {. De } \\
\text { agosto/ } \\
\text { Cascavel }\end{array}$ & $01 / 08 / 2004$ & $\begin{array}{l}\text { Em 07/02/2004 } \\
\text { - inauguração } \\
\text { oficial, mas } \\
\text { novembro de } \\
2003 \text { foi o } \\
\text { início das } \\
\text { atividades }\end{array}$ & $\begin{array}{l}\text { Incorporou a EI Oziel Alves } \\
\text { em 2012, passando a } \\
\text { funcionar no Pré- } \\
\text { Assentamento Valmir Motta }\end{array}$ \\
\hline $\begin{array}{l}\text { Escola } \\
\text { Itinerante } \\
\text { Sementes do } \\
\text { Amanhã }\end{array}$ & $\begin{array}{l}\text { Chico Mendes/ } \\
\text { Matelândia (distrito de } \\
\text { Agro Cafeeira) }\end{array}$ & $31 / 07 / 2004$ & Nov/2004 & $\begin{array}{l}\text { Continua funcionando como } \\
\text { escola de acampamento }\end{array}$ \\
\hline $\begin{array}{l}\text { Escola } \\
\text { Itinerante Paulo } \\
\text { Freire }\end{array}$ & $\begin{array}{l}\text { Acampamento } \\
\text { Primeiro de Maio e em } \\
2007 \text { itinera para o } \\
\text { Acampamento Reduto } \\
\text { de Caraguatá/em } \\
\text { Paula Freitas) } \\
\end{array}$ & $01 / 05 / 2003$ & $08 / 06 / 2003$ & $\begin{array}{l}\text { Continua funcionando como } \\
\text { escola de acampamento }\end{array}$ \\
\hline $\begin{array}{l}\text { Escola } \\
\text { Itinerante } \\
\text { Caminhos do } \\
\text { Saber }\end{array}$ & $\begin{array}{l}\text { Acampamento Maila } \\
\text { Sabrina/ Fazenda } \\
\text { Brasileira Ortigueira }\end{array}$ & 2003 & 2007 & $\begin{array}{l}\text { Continua funcionando como } \\
\text { escola de acampamento }\end{array}$ \\
\hline $\begin{array}{l}\text { Escola } \\
\text { Itinerante Maria } \\
\text { Aparecida } \\
\text { Rosignol } \\
\text { Franciosi } \\
\end{array}$ & $\begin{array}{l}\text { Eli Vive/ } \\
\text { Londrina }\end{array}$ & $\begin{array}{l}1^{a} \text {. Ocupação } \\
\text { em } 1991 \text { e } \\
\text { segunda } \\
\text { ocupação em } \\
2009\end{array}$ & 2010 & $\begin{array}{l}\text { Continua funcionando como } \\
\text { escola de acampamento }\end{array}$ \\
\hline $\begin{array}{l}\text { Escola } \\
\text { Itinerante } \\
\text { Valmir Motta } \\
\text { de Oliveira } \\
\end{array}$ & $\begin{array}{l}\text { Companheiro Keno/ } \\
\text { Jacarezinho }\end{array}$ & 2008 & 2008 & $\begin{array}{l}\text { Continua funcionando como } \\
\text { escola de acampamento }\end{array}$ \\
\hline $\begin{array}{l}\text { Escola } \\
\text { Itinerante } \\
\text { Carlos } \\
\text { Marighella }\end{array}$ & $\begin{array}{l}\text { Elias Gonçalves de } \\
\text { Meura/ } \\
\text { Planaltina do Paraná }\end{array}$ & $31 / 07 / 2004$ & $\begin{array}{l}\text { Setembro de } \\
2004\end{array}$ & $\begin{array}{l}\text { Continua funcionando como } \\
\text { escola de acampamento }\end{array}$ \\
\hline
\end{tabular}




\begin{tabular}{|l|l|l|l|l|}
\hline $\begin{array}{l}\text { Escola } \\
\text { Itinerante } \\
\begin{array}{l}\text { Construtores do } \\
\text { Futuro }\end{array}\end{array}$ & $\begin{array}{l}1^{\circ} \text {. De setembro/ } \\
\text { Rio Branco do Ivaí }\end{array}$ & $01 / 09 / 2007$ & 2010 & $\begin{array}{l}\text { Continua funcionando como } \\
\text { escola de acampamento }\end{array}$ \\
\hline $\begin{array}{l}\text { Escola } \\
\text { Itinerante } \\
\text { Herdeiros da } \\
\begin{array}{l}\text { Luta de } \\
\text { Porecatu }\end{array}\end{array}$ & $\begin{array}{l}\text { Perdeiros da Luta de } \\
\text { Porecatu/ }\end{array}$ & 2008 & 2009 & $\begin{array}{l}\text { Continua funcionando como } \\
\text { escola de acampamento }\end{array}$ \\
\hline
\end{tabular}

Fonte: Bahniuk (2008), coleta de dados nos locais pela pesquisadora; MST (2008 a); MST (2008 b); MST (2011a); MST (2011b); contribuições de Daniela Carla de Oliveira (até início de 2011 integrante da equipe de Coordenação de Educação do Campo da SEED/PR), Relatórios das EI de 2006 e 2009. Quadro elaborado pela autora.

Após conhecer, observar e analisar a situação em que se encontram as escolas itinerantes do Paraná, percebemos contradições e uma distância muito grande entre o que se quer e o que se consolida, mesmo assim pudemos reconhecer um esforço coletivo bastante importante na busca de alternativas para se avançar na construção e implementação da proposta pedagógica.

Antes de analisarmos as questões de infraestrutura das Escolas Itinerantes, gostaríamos de explicitar um pouco as relações de produção que envolvem os moradores dos acampamentos visitados e que, de certa forma, são determinantes de alguns encaminhamentos feitos na escola. Há vários aspectos importantes a serem analisados: o esvaziamento dos acampamentos, a exploração do trabalho e o seu caráter contraditório. Percebemos pelos relatos feitos, que a maioria dos acampamentos tinham, em 2012, bem menos famílias do que no período de 2003/2004 ou no início de cada ocupação e isso causa um grande desânimo. Em consequência disso, percebemos em algumas escolas, desânimo e pouco envolvimento da comunidade que é, justamente, reflexo do desânimo na luta, que é longa para alguns (alguns militantes moram, por exemplo, há mais de vinte anos em acampamento), e isso se deve, principalmente, à ausência ou insuficiência de políticas para a Reforma Agrária e à extrema concentração da propriedade da terra no Brasil, a qual se mantém praticamente intocada. Há uma demora e até estagnação nas ações do governo em relação à questão. Assim, entendemos que o processo de desestruturação da luta causa também um processo de desestruturação da escola itinerante, porque ela está organicamente vinculada ao Movimento. Assim, esse estado de coisas que é consequência, principalmente, da consolidação de políticas governamentais inócuas, morosas e que não atendem às necessidades da classe trabalhadora, impõe ao MST a exigência de reavaliar e rearticular estratégias de luta, levando-o no momento atual, a fortalecer acampamentos e assentamentos já existentes para, num momento posterior, ampliar a abrangência de suas ações.

Nesse processo, para sobreviver nos acampamentos muitos são submetidos à exploração, a uma condição desumana de trabalho, desde a forma utilizada para chegar ao local de trabalho (a pé, em veículos pouco seguros) até o valor pago (às vezes, o trabalho duro de um dia inteiro rende apenas $\mathrm{R} \$ 20,00)$. Além disso, como a maior parte dos contratos é feita por dia (sem contrato formal), não há garantia de nenhum direito trabalhista. Há uma superexploração da força-de-trabalho. Muitos desses trabalhadores, trabalham em fazendas que ficam no entorno dos acampamentos ou nas próprias propriedades onde o acampamento se encontra, outros chegam a ir para a cidade ou localidades próximas. Em alguns casos, o trabalhador chega a ficar toda semana longe da família para trabalhar fora do acampamento.

Há também presente nessas relações aspectos de contradição. Um deles se explicita no fato de que os mesmos trabalhadores que ocupam a propriedade privada de um capitalista, para sobreviver, precisam vender sua força de trabalho para ele. O seu 
adversário na luta de classes também é o seu explorador. Isso é compreensível nessa sociabilidade, uma vez que a primeira condição para fazer história, segundo Marx, é estar vivo. Enquanto não se conquista o meio de produção, vende-se a força-de-trabalho para quem o detém. Outras vezes a contradição reside nas próprias relações estabelecidas entre os integrantes do Movimento quando pagam, por exemplo, $\mathrm{R} \$ 160,00$ a hora de trabalho do trator, que pertence a um dos acampados. Há, nesse caso, exploração entre os próprios companheiros de luta.

Para se reproduzir, o capital, mesmo num momento de automação, de predomínio do trabalho morto sobre o trabalho vivo, apropria-se de toda forma de trabalho, mesmo do braçal e não qualificado. Percebemos nas entrevistas feitas e nas visitas, o baixo nível de escolaridade dos adultos que moram nos acampamentos - a maioria tem menos de quatro anos de escolaridade. Em alguns locais, o que sobra para o trabalhador é o trabalho que as máquinas não fazem. Isso acontece, principalmente, nas fazendas que produzem café e cana-de-açúcar (mais ao norte do estado), que aos poucos estão trocando o trabalho vivo pelo trabalho morto ${ }^{21}$. Ao fazê-lo, o capitalista objetiva minimizar o valor. As justificativas apresentadas pelo capitalista não incluem esse motivo, outros são apontados para encobrilo. Os produtores de cana, por exemplo, alegam que as exigências ambientais (redução em $25 \%$ das queimadas em cinco anos, por exemplo, pela Lei 11.241/2002) os obrigam a adquirir as máquinas. Outros explicam que é preciso modernizar a produção para enfrentar a competição internacional. Realmente, para reproduzir o capital, sacrifica-se não só o trabalhador, mas se necessário for, o próprio capitalista. Impõe-se tanto a um como a outro a exigência de se adaptar aos novos processos de produção capitalista. A troca crescente do trabalho vivo pelo trabalho morto expressa uma das contradições do capital, pois, somente o trabalho vivo produz mais-valia.

De acordo com Tavares (2004, p 62), "o capital, tal qual uma entidade divina, tem a propriedade da onipresença. Todos os espaços econômicos e sociais foram ocupados por ele, de modo que qualquer forma de trabalho está irremediavelmente, subordinada à produção capitalista".

Em geral, nos acampamentos visitados, o trabalho está associado à produção de matéria-prima para indústrias que estão na região onde se situam os acampamentos, pois, há um processo de integração, ou melhor, de subordinação da agropecuária à indústria.

Em muitos casos, os acampados são prestadores de serviço aos donos das fazendas que oferecem matéria-prima à indústria, mas em alguns casos, eles próprios são os fornecedores. Por exemplo, em Guairaçá, os acampados trabalham na colheita da mandioca nas fazendas vizinhas e recebem $\mathrm{R} \$ 26,00$ por dia e também vendem para a indústria a parte produzida no acampamento, recebendo em torno de $\mathrm{R} \$ 200,00$ por tonelada. Se vendessem na cidade, como é o caso dos acampados, em Jacarezinho, receberiam $\mathrm{R} \$ 1,00$ por quilo.

Esses exemplos mostram claramente que a contradição está entre ser proprietário e não ser proprietário, entre capital e trabalho. Também demonstram que a reestruturação produtiva levou muitos trabalhadores à informalidade que é "um fenômeno que faz parte da dinâmica econômica e social" (TAVARES, 2004, p. 42), portanto, do atual momento do capitalismo.

Praticamente todo trabalho realizado pelos acampados, fora do acampamento, em busca de ampliação da renda familiar é feito na informalidade. É o caso das mulheres que realizam trabalho doméstico; dos acampados que trabalham como boias-frias, como pedreiros, na colheita e no plantio, na criação de animais e outros, não tendo registro em carteira ou qualquer direito trabalhista garantido. Tavares (2004) apresenta elementos que contribuem para compreender essas questões. Segundo ela, a informalidade parece camuflar as relações de exploração, pois, dão uma falsa impressão de autonomia, de parceria e até de liberdade. Essa informalidade só é possível porque há uma 
desregulamentação das relações de produção e um recuo do aparato jurídico de proteção do trabalho. O trabalho é a única mercadoria que produz valor, portanto, só se produz maisvalia com força-de-trabalho e na informalidade se potencializa essa possibilidade, pois, ela representa uma redução de custos e está pautada, muitas vezes, em produtividade, ou seja, recebe-se pela quantidade produzida.

Trabalho informal, portanto, se constitui numa estratégia funcional ao capital, especialmente nessa era de acumulação flexível, em que a diversidade de status de assalariado permite, com maior liberdade, uma exploração mais intensa dessa forma de trabalho, pela articulação sistemática da mais valia absoluta com a mais valia relativa. (TAVARES, 2004, p. 48)

Conforme a autora, os encargos trabalhistas, hoje, representam um entrave para a reprodução ilimitada do capital e com essa desregulamentação do trabalho e a substituição do trabalho vivo pelo trabalho morto, tornou-se possível extrair mais-valia sem que haja uma relação direta e explícita de assalariamento. Pudemos perceber que os acampados ficam sem saída e a informalidade se apresenta como um mal menor diante do desemprego que se expande em consequência da modernização dos processos de produção no campo, que incorporam as tecnologias mais avançadas. Individualmente, cada um busca uma saída para sobreviver sem se dar conta de que todos fazemos parte do "trabalhador coletivo" (TAVARES, 2004, p. 124) e, mesmo quando se tem consciência disso, precisa garantir a sobrevivência. Em geral, portanto, os trabalhadores não têm como meta a acumulação, mas a sobrevivência. Essa situação ultrapassa a fronteira entre campo e cidade e atinge toda classe trabalhadora, pois, a questão central é a sobrevivência, a reprodução. Se no campo o trabalho informal ocorre nas atividades de plantio, de colheita, de criação de animais e outros, na cidade ela ocorre também em variadas atividades do comércio, da indústria e da prestação de serviços, por exemplo.

Ao se encontrarem nessa situação, muitas famílias acabam dependendo também das ações assistencialistas do governo. É o caso das famílias que recebem, de três a quatro vezes por ano, a cesta básica fornecida pelo governo ou ainda, que recebem o Bolsa Família.

A situação em que se encontram os acampados, em relação ao trabalho, é muito próxima da situação de grande parte dos trabalhadores no Brasil. Segundo dados do DIEESE (2011), em 2009: 41,7\% dos ocupados em atividades agrícolas trabalhavam em lavouras temporárias; apenas $16,8 \%$ dos trabalhadores do campo tinham emprego permanente; $83,6 \%$ dos trabalhadores do campo não contribuíam com a previdência; o rendimento médio mensal dos trabalhadores do campo era $\mathrm{R} \$ 495,00$ (homens) e 255,00 (mulheres). Em 2010, foram libertados 2628 trabalhadores, em 309 fiscalizações feitas em fazendas.

Não encontramos nos acampamentos precariedade só no trabalho realizado pelos acampados, mas também das condições de trabalho dos educadores e das estruturas das escolas. A realização de qualquer proposta pedagógica exige condições estruturais adequadas, e estas vão desde estrutura física à formação de educadores. Isso significa dizer que a limitação é objetiva e não fruto meramente da vontade dos envolvidos. Partimos do entendimento que não se constrói um processo educativo que possibilite acesso amplo ao conhecimento produzido pela humanidade, na precariedade. Também não defendemos o outro extremo, o de entender que ter as condições estruturais seja garantia, por si só, para a consolidação desse processo.

Os educadores entrevistados das escolas apontam várias dificuldades encontradas para avançar com qualidade na implementação da proposta pedagógica. A maioria indica 
como problemas/dificuldades principais: a estrutura física das escolas (há, inclusive, relatos de que inúmeras vezes a escola foi destruída por temporais e teve que ser reconstruída); a perda de dias letivos (por causa das chuvas e situação das estradas); a forma de contratação dos educadores que contribui para a grande rotatividade dos mesmos; o desânimo de algumas comunidades em relação à escola, pois o comprometimento com a escola já foi maior; dificuldades em se organizar o planejamento coletivo com os educadores dos anos finais do Ensino Fundamental e Médio por causa da fragmentação dos horários e por trabalharem em várias escolas, permanecendo pouco na escola, por isso, também se consegue avançar pouco na proposta do trabalho por área; a falta de acesso a telefone, à internet e a outras tecnologias; falta de materiais para realizar as atividades; falta de atendimento às crianças com necessidades especiais nos acampamentos, que acabam, em geral, sendo levadas para as cidades vizinhas para tal ou ficam sem atendimento; a falta de domínio de conteúdo por parte de alguns educadores; o número reduzido de pessoas para acompanhar e assessorar os educadores no processo pedagógico; a omissão do governo para garantir condições adequadas de trabalho. A seguir detalhamos algumas dessas questões.

A primeira questão diz respeito à estrutura física. A maioria das salas de aula é de madeirite, sem assoalho, sem ventilação e sem iluminação adequadas. A situação da iluminação é ainda mais grave quando se trata do ensino noturno. As instalações para banheiro, são, em geral, pouco higiênicas. Na maioria dos casos, são utilizadas patentes externas, bem precárias. Em algumas, a comunidade até se organizou para colocar água encanada para eliminar os dejetos. Apesar dos pedidos protocolados junto à SEED, a situação não foi resolvida. A precariedade encontrada nas bibliotecas e o pouco acesso às tecnologias são fatores que dificultam enormemente o processo de pesquisa escolar, limitando, consequentemente, o acesso à informação. Os educadores não têm, em alguns casos, livros didáticos suficientes para levar para a sala de aula. Há escola que não têm sequer mimeógrafo para reproduzir material, restando ao educador o registro daquilo que ele próprio anota resumidamente no quadro de giz.

Outro aspecto diz respeito à formação continuada. Nos arquivos do Movimento encontramos vários registros de processos de formação continuada, em várias modalidades. Nos acampamentos são realizados grupos de estudo semanais, mas que acabam envolvendo mais os educadores dos anos iniciais por morarem no próprio acampamento. A coordenação do Coletivo Estadual de Educação do MST também organiza, em parceria com Universidades, governo federal e a SEED alguns encontros regionais e estaduais. Nesses encontros, em geral, há dois enfoques: questões relacionadas especificamente à luta, à militância e relacionadas mais especificamente ao processo educativo escolar. $\mathrm{Na}$ primeira questão são discutidos temas relacionados à estrutura fundiária, à conjuntura político-social, à situação social; ao processo da luta de classes, à forma de produção da vida no campo e outros. A segunda questão traz para a formação, discussões relacionadas à proposta pedagógica, ou seja, à busca do entendimento dos elementos que compõem a proposta dos Ciclos de Formação Humana e também são articulados encaminhamentos teórico-práticos que são definidos a partir das dificuldades encontradas no trabalho pedagógico. São realizadas oficinas para trabalhar conteúdos de diferentes áreas, são feitos exercícios de planejamento coletivo, buscando confrontar e analisar diferentes formas de fazê-lo. Percebemos que as formações política e pedagógica não se separam em nenhum momento e que nos encontros há um processo permanente de avaliação da proposta pedagógica. Vários encontros foram realizados nos últimos anos em Faxinal do Céu, Cascavel, Matelândia, Curitiba, Londrina e demais acampamentos onde se situam as escolas itinerantes. Desses encontros participaram educadores, coordenadores, pessoas da comunidade, pesquisadores e estudantes. 
Esses encontros regionais e estaduais são feitos, em geral, com bastante precariedade, pois, nem sempre contam com financiamento do Estado, que deveria ser o mantenedor das escolas. Em 2011, segundo depoimento de um dos coordenadores do Coletivo Estadual de Educação ${ }^{22}$, não houve financiamento para nenhum momento de formação continuada. Mesmo assim, o Movimento se organizou e promoveu vários encontros, alojando os participantes nos barracos do acampamento onde os encontros foram realizados. Mesmo com tanto esforço, percebemos que a formação continuada acaba acontecendo de forma precária e com rupturas, pois, não há continuidade que possa levar a um aprofundamento e há rotatividade muito grande dos educadores. O MST tem sido firme no sentido de definir o conteúdo no processo de formação. Em 2012, no mês de maio, foi feito o primeiro encontro de formação continuada, em parceria com o governo Richa, em Curitiba, com os educadores dos anos iniciais das escolas itinerantes. Houve financiamento por parte do governo, mas também pressão em relação ao controle do conteúdo do mesmo. Em outubro de 2012, houve um encontro com os coordenadores das escolas itinerantes e das escolas-base para analisar a proposta dos complexos de estudo, sem apoio financeiro do estado. Apesar desse esforço de formação continuada, percebemos pouco avanço nas práticas pedagógicas realizadas nas escolas. Consideramos que isso ocorre pelos seguintes motivos: um deles é a rotatividade dos educadores, portanto, não há continuidade e nem aprofundamento na compreensão das questões teórico-práticas; outro é a precária formação inicial de muitos educadores, principalmente dos anos iniciais do Ensino Fundamental e da Educação Infantil que impede o aprofundamento teórico-metodológico, limitado pela falta de domínio de conteúdos; e um terceiro motivo é a precariedade das condições de trabalho.

Além da formação continuada, há outros aspectos a serem analisados em relação aos educadores: o perfil, a formação inicial, o vínculo e o aceite em relação ao próprio MST e as condições de trabalho. Constatamos que grande parte dos educadores da Educação Infantil e dos anos iniciais do Ensino Fundamental que atuava até 2011, não tinha formação adequada, ou seja, em alguns casos, ainda estavam cursando o Ensino Médio, de formação geral, no próprio acampamento. Alguns estão em processo de formação em cursos de Magistério, Pedagogia e outras licenciaturas (do campo, Geografia e outras), em geral, em cursos em regime de alternância, por isso, afastando-se das atividades em vários momentos durante o ano letivo. A curto prazo, isso acarreta um problema, mas representa um instrumento para qualificar o processo educativo, a médio prazo, que é uma das preocupações permanentes da coordenação do coletivo estadual de Educação do Movimento. Há, nesse aspecto, um avanço importante, pois nos últimos anos, por meio de editais do MEC e parcerias com as Universidades públicas, alguns desses educadores cursaram ou estão cursando o Ensino Superior. Ocorre, porém, que grande parte deles, por necessidade da própria organização do Movimento, acaba não indo para a sala de aula, permanecendo no trabalho interno das Universidades, acompanhando esses cursos, na coordenação do Coletivo Estadual de Educação do MST ou em projetos. Não se pode, assim, sentir ainda o impacto desses cursos nas salas de aula das escolas pesquisadas.

Apesar das dificuldades, manter o quadro da Educação Infantil e dos anos iniciais do Ensino Fundamental com militantes do Movimento é uma tentativa de possibilitar maior proximidade entre a escola e o Movimento. A tarefa dada aos educadores dos anos iniciais e Educação Infantil, em geral, considerando sua formação e experiência, é pesada demais, e até impossível, nessas condições de ser realizada com qualidade, não garantindo avanços significativos no processo educativo. Alguns não têm a mínima condição de estar em uma sala de aula, pois, não têm domínio de conteúdo.

O perfil do quadro de educadores da Educação Infantil e anos iniciais do Ensino Fundamental teve uma mudança significativa após a assinatura do Convênio $2620110046^{23}$, entre a ACAP e o governo do estado do Paraná. Nesse Convênio, a SEED exigiu que os educadores tivessem no mínimo o curso de formação docente (previsto 
como exigência mínima, no artigo 62 da LDB 9394/96) ou estivessem cursando uma licenciatura. No Relatório da ACAP, do primeiro semestre de 2012, aparecem 105 contratados, sendo 64 educadores (17 com Magistério, 22 com Pedagogia, 17 com Licenciatura em Educação do Campo, 7 com Ensino Médio e 1 com Licenciatura em Arte); 13 merendeiras (12 com Ensino Médio e 1 com anos iniciais do Ensino Fundamental); 10 auxiliares administrativos (9 com Ensino Médio e 1 com Magistério); 13 coordenadores (9 com Pedagogia, 1 com Licenciatura em Geografia e 3 com Licenciatura em Educação do Campo) e 5 funcionários para a biblioteca (4 com Ensino Médio e 1 com Magistério) (MST, 2012 b).

Interessante registrar aqui que antes do Convênio 2012/2013, todo trabalho de serviços gerais, preparação de merenda, auxiliar administrativo, serviços de biblioteca eram prestados voluntariamente pela comunidade, portanto, sem rendimentos. Com esse convênio, o governo passou a remunerar esses serviços, porém, outros (como construção de salas, organização dos espaços externos e outros) continuam sendo voluntários e expressam dois aspectos: de um lado, a organização da comunidade e o compromisso com a luta; de outro, a desresponsabilização do Estado com as políticas sociais, nesse caso, a educação, especialmente quando destinada à classe trabalhadora organizada na luta.

Os educadores dos anos finais do Ensino Fundamental e os do Ensino Médio, em sua grande maioria, são licenciados e até com pós-graduação (encontramos um com Mestrado). O que chama a atenção é que muitos estão em início de carreira e acabam indo para as escolas itinerantes porque estavam no final da lista de classificação, feita pela SEED, a partir do Processo Seletivo Simplificado e não tinham outra opção. Alguns atuam fora da área de formação. Há uma rotatividade muito grande, pois, assim que abre vaga em escolas da cidade ou mais próximo de suas casas, muitos acabam pedindo transferência. Como grande parte é contratada pelo Processo Seletivo Simplificado, ou seja, tem contrato temporário, mesmo querendo permanecer na escola itinerante, quando começam novo contrato, acabam indo para outras escolas. Poucos são os que permanecem de um ano para outro nas escolas itinerantes. Há ainda casos em que o educador apresenta rejeição ao Movimento, o que o impede de 'adotar' a proposta pedagógica em seus fundamentos, principalmente, no que diz respeito à formação política. Houve casos em que o educador, quando chamado para assumir aulas, sabendo que se tratava de escola de acampamento do MST, não as assumia.

Um dos fatores que mais contribui para a rotatividade desse segundo grupo é a falta de condições de trabalho. Não há um pagamento diferenciado para custear o deslocamento para locais mais afastados dos centros urbanos. Há relatos de educadores que chegam a gastar em torno de R \$ 400,00 para deslocamento. No Acampamento Eli Vive, por exemplo, durante os primeiros meses de 2011, a comunidade gastava em torno de $\mathrm{R} \$$ 1000,00 para cobrir o deslocamento dos educadores que vinham de fora. Como a comunidade tinha dificuldades financeiras, não conseguiu continuar bancando e a suspensão da ajuda gerou, inclusive, o pedido de demissão de uma das educadoras. Alguns educadores chegam a percorrer $140 \mathrm{~km}$, diariamente, para chegar às escolas, usando seu próprio carro e bancando as despesas com esse transporte. Em geral, não há opção de ônibus para chegar às escolas itinerantes. Como, muitas vezes, as estradas estão em péssimas condições, além da rotatividade, há faltas dos educadores no dia-a-dia, o que acarreta um prejuízo enorme aos educandos. Percebemos que, por vezes, poderiam estar na escola, mesmo com as estradas ruins, mas isso facilmente serve para justificar faltas.

Segundo relatório apresentado pela ACAP à SEED, no decorrer do primeiro semestre de 2012:

[...] os sujeitos que passaram pelo quadro funcional da Escola Itinerante totalizam 200 pessoas, sendo que 125 foram por meio do Convênio celebrado entre a ACAP e SEED, destes 60 são professores, 11 
merendeiras, 28 Auxiliares administrativos, 07 Auxiliares de Serviços Gerais e 19 coordenadores pedagógicos, e os outros 75 são professores contratados por meio do processo seletivo simplificado. (MST, $2012 \mathrm{a}, \mathrm{p}$. 3)

Há casos em que, os educadores que vêm das cidades vizinhas e têm dois ou três dias de aula no acampamento, ficam alojados em um barraco ou casas que já existiam nas fazendas, nesses dias. Estes, acabam criando um vínculo mais forte com a comunidade e conhecendo um pouco mais a realidade vivida pelos acampados.

Interessante perceber que há diferentes percepções dos acampados em relação aos educadores que vêm da cidade trabalhar nas escolas itinerantes e que não têm vínculo com o Movimento. Uma das lideranças de um dos acampamentos ${ }^{24}$ considera que os educadores que vêm de fora, contribuem para aproximar a comunidade externa do Movimento. Outra entrevistada ${ }^{25}$ considera que quando o educador é do Movimento ele entende melhor a escola no contexto da luta e quando vem da cidade se coloca, muitas vezes, numa posição de suposta neutralidade. Também percebemos, em geral, um distanciamento entre os educadores que são do acampamento e os que vêm das cidades vizinhas.

Outra problemática que envolve as escolas itinerantes é que toda documentação e cadastro dos educandos são feitos pela escola-base. Isso gera algumas polêmicas. A primeira diz respeito ao fato dos educandos estarem no município onde fica a escola itinerante mas, para fins de liberação de recursos, serem contados no censo do município da escola-base. Também há o fato da escola-base, em alguns casos, estar a mais de $300 \mathrm{~km}$ da escola itinerante. Como o estado não viabiliza condições adequadas para mobilização de pessoal de uma até outra escola, os processos de pedido e envio de documentos se tornam morosos. Com a troca de coordenação da Educação do Campo, na Secretaria de Estado da Educação do Paraná, em 2011, o debate sobre a descentralização veio à tona. Em 2011, o setor de educação do MST no Paraná, problematizou essa questão indicando sua preocupação no sentido de que se fossem escolhidas mais escolas-base para descentralizar, que fossem de Assentamento do Movimento e que essas escolas-base assumissem a proposta das itinerantes e não o contrário.

Além dessas questões, percebemos que o fato das crianças estudarem no Acampamento atende as necessidades das famílias, evita que sejam transportadas para a cidade, permite discussões políticas vinculadas à luta organizada pelo Movimento, mas, por outro lado, os retira da possibilidade de frequentarem uma escola maior, com melhor infraestrutura e recursos pedagógicos e as isola do convívio com outras crianças. Tal questão já havia sido apontada por Grein e Gehrke (2008, p. 95), que expressam a seguinte preocupação:

A escola dentro do acampamento é um grande avanço, por outro lado isola as crianças das relações com outras crianças vindas de situações diversas. As relações com outros grupos sociais são importantes para a sua formação social e entendimento da globalidade das relações nos processos de transformação social. Daí a necessidade de estarmos sempre atentos e contemplar no currículo e no planejamento da Escola Itinerante atividades que permitam visitar outras escolas no campo e na cidade, feiras, cinema, passeios pedagógicos diversos, fazer pesquisas, trocar experiências.

Outro aspecto que nos chamou a atenção é a homenagem que se faz a militantes que sacrificaram suas vidas pela causa do Movimento ao se nomear várias das escolas e acampamentos com seus nomes. Isso é uma marca da luta. Por outro lado, tem caráter 
contraditório, pois cria heróis individuais num processo coletivo de luta, mas mesmo na contradição é um importante ato de reconhecimento e de registro de uma 'memória de resistência'.

Apesar da precariedade encontrada, a escola itinerante, sem dúvida, é instrumento estratégico no processo de ocupação e resistência. Houve caso em que o despejo foi evitado por causa da existência da escola e de muitas crianças nela estudando, como por exemplo, em Matelândia, no Acampamento Chico Mendes. Manter a escola itinerante funcionando é importante. Igualmente importante é construir, a médio prazo, as condições para qualificá-la na luta. A existência de escolas em acampamentos é um marco político da luta $^{26}$. Segundo Martins (2004, p. 75), "a ocupação, não somente da terra, mas também da escola, configura-se com materialização da luta de classes".

Percebemos que há uma diferenciação entre as escolas, fato que está intimamente relacionado ao contexto da luta possível em cada acampamento, ou seja, a possibilidade de produzir a vida com mais dignidade, o acesso a uma área maior de terra para plantar e a própria organização coletiva impulsiona a escola e o envolvimento entre ela e a comunidade de forma diferente.

A própria itinerância da escola é definida pelo movimento da luta, ou seja, se há despejo no acampamento, há despejo na escola; se há fim de um acampamento, há fim da escola; se há mudança para outro espaço, há mudança da escola. Essa natureza de itinerância é necessária e possibilita que a escola seja parte da luta e por outro lado, dificulta a consolidação de qualquer proposta pedagógica.

O caráter de itinerância está ligado à itinerância do grupo que mora no acampamento e deveria ser provisório, porém, essa provisoriedade acaba ganhando caráter de permanência longa, considerando que encontramos famílias que moram há mais de 20 anos, em diferentes acampamentos, no Paraná e outros, há mais de nove anos em um mesmo acampamento. Isso expressa a morosidade do Estado na execução de políticas sociais, nesse caso, relacionadas à função social da terra, que é consequência do seu caráter de classe.

Apesar de todas as dificuldades, conta uma das coordenadoras ${ }^{27}$, a escola foi responsável pela formação de várias lideranças e educadores que hoje estão em escolas do Movimento ou mesmo na coordenação do coletivo estadual e que muitos deles concluíram o Ensino Superior e até Mestrado depois de passar pela EI.

Considerando essas questões, não podemos deixar de explicitar o papel do Estado nesse processo que, amparado pela justificativa da ilegalidade e provisoriedade dos acampamentos, tem propiciado apenas condições precárias para a realização do trabalho nessas escolas e tem se posicionado no sentido até de controlar o conteúdo do ensino e do processo de formação continuada dos educadores; tem desarticulado a equipe composta dentro da SEED/PR para acompanhar essas escolas, impondo, inclusive, profissionais que se encontram alheios à situação. Essa precarização parece interessar ao Estado, pois, impede a consolidação da proposta.

\section{Considerações finais}

É nesse estado de precariedade, mas de posicionamento político demarcado, que se encontram hoje as escolas itinerantes do Paraná. É esse estado de coisas que contribui para limitar a construção de uma proposta contra-hegemônica de educação. Mesmo assim, há avanços e soma de esforços para superar e romper com a tradicional escola capitalista. A existência das escolas itinerantes representa a ocupação da escola e como vários entrevistados afirmaram, é um avanço, um posicionamento de resistência.

A existência das escolas itinerantes, o esforço em construir uma proposta contrahegemônica de educação, a inserção da escola em contexto de luta organizada expressa que 
outra educação é possível, porém, não sem aliar proposta pedagógica, compromisso político e luta. O MST tem sido um dos poucos sujeitos coletivos a construir esses espaços/tempos de resistência, portanto, sujeito que pode nos ensinar o caminho para isso e que, ao mesmo tempo, precisa da agregação de muitos sujeitos para avançar.

O MST nos instiga nesse processo de criação das escolas itinerantes com uma proposta pedagógica fundada no entendimento da educação como processo de formação humana em suas diferentes dimensões, a potencializar esforços no sentido de construir a contra-hegemonia educacional, não como solução, mas como instrumento de luta da classe trabalhadora na perspectiva da emancipação humana plena.

\section{Referências}

BAHNIUK, Caroline. Educação, trabalho e emancipação humana: um estudo sobre as escolas itinerantes do acampamentos do MST. 2008. Dissertação (Mestrado em Educação). Universidade Federal de Santa Catarina. Florianópolis, 2008. 180p.

CAMINI, Isabela.Escola itinerante na fronteira de uma nova escola. São Paulo: Expressão Popular, 2009.

CAMINI, Isabela e RIBEIRO, Marlene. Escola itinerante: onde escola, luta e vida se entrecuzam. IN: VENDRAMINI, Célia Regina e MACHADO, Ilma Ferreira (orgs). Escola e movimento social: experiências em curso no campo brasileiro. São Paulo: Expressão Popular, 2011.

CPT. Desterro. Uma cronologia da violência no campo no Paraná na década de 90. Curitiba: CPT, 2006.

CRISTO, Luciana. Sem Terra ocupam fazenda em Porecatu. Paraná on line. 4/11/2008. Disponível em http://www.paranaonline.com.br/editoria/cidades/news/332776/?noticia=SEM+TERRA+OCUPAM+FAZEN DA+EM+PORECATU. Acesso em 22 de julho de 2011.

DATALUTA. Banco de dados da luta pela terra. Relatório 2006. Coordenação Geral Bernardo Mançano Fernandes. Disponível em HTTP://cacphp.unioeste.br/projetos/geolutas/projetos_dataluta_relatorios.php. Acesso em 31/05/2011.

DIEESE. Estatísticas do meio rural 2010-2011. 4 ed. Brasília, MDA, 2011.

GREIN, Maria Izabel e GEHRKE, Marcos. Escola Itinerante no desafio da luta pela Reforma Agrária. In: MST. Itinerante: a escola dos Sem Terra - trajetórias e significados. Cadernos da Escola Itinerante - MST. Ano I - no. 2 - Outubro de 2008. Curitiba: SEED, 2008.

MANOEL, Lawrence. MST invade área de preservação ambiental. 22/02/2005. Disponível em http//:Paranáonline.com.br/editorial/cidades/news/112476/?noticia=MST+invade+área+de+preservacao +ambiental. Acesso em 01 de maio de 2012.

MARTINS, Fernando José. Gestão democrática e a ocupação da escola. O MST e a educação. Porto Alegre: EST, 2004. 
MAZZAROLLO, Juvêncio. A taipa da injustiça. Esbanjamento econômico, drma social e holocausto ecológico em Itaipu. São Paulo: Loyola, 2003.

MORISSAWA, Mitsue. A história da luta pela terra e o MST. São Paulo: Expressão Popular, 2001.

MST. Só quem sabe tem condições de dirigir . Jornal Sem Terra. Número 62, ano VI, maio de 87, p. 16, 1987 a

. Sabendo fazer a luta será melhor. Jornal Sem Terra. Número 65 , ano VI, agosto de 87, p. 16,1987 b 16,1988

É preciso saber fazer. Jornal Sem Terra. Número 71, ano VIII , março de 88, p. 1989 a

Educar á ato político. Jornal Sem Terra. Número 81, ano IX, março de 89, p. 16,

Memória. Jornal Sem Terra. Número 82, ano IX , abril de 89 , p. 20, 1989 b

. Relatório das escolas itinerantes de 2006. Curitiba, 2006.

Itinerante: a escola dos Sem Terra - trajetórias e significados. Cadernos da Escola Itinerante - MST. Ano I - no. 2 - Outubro de 2008. Curitiba: SEED, 2008 a

Relatório das escolas itinerantes de 2008. Curitiba, 2008 b

. Relatório das escolas itinerantes de 2009. Curitiba, 2009

- Memória dos encontros realizados na construção dos Complexos de Estudo. Curitiba: 2011 a (mimeo)

Ciclos de formação humana na Escola. Colégio Estadual Iraci Salete Strozak e Escolas Itinerantes. Curitiba: SEED, 2011 b

Relatório das escolas itinerantes de 2012 (1º. Semestre). Curitiba, 2012 a

. Lista de contratados e formação. 2012 (1 ${ }^{\circ}$. Semestre). Curitiba: MST, 2012 b.

s/d. (mimeo)

Organização da Escola Itinerante de Educação Infantil ao Ensino Médio. Curitiba,

PIRES, Ariel José. O Movimento dos Trabalhadores Rurais Sem Terra e a política social católica (1980 a 2000). Concepções, ambiguidades e permanências na luta pela terra agrícola. Tese (Doutorado). Faculdade de Ciências e Letras da Universidade Estadual Paulista. Assis/SP, 2001. 167p.

SEM-TERRA negam ter torturado madeireiro no sudoeste paranaense. 28/09/2006. Disponível em http//:radioagencianp.com.br/node/798. Acesso em 01 de maio de 2012.

SERRA, Elpídio. Processos de ocupação e luta pela terra agrícola no Paraná. Tese apresentada ao Instituo de Geociências e Ciências Exatas da Universidade Estadual 
Paulista Julio de Mesquita Filho. UNESP. Rio Claro. Doutorado em Geografia, 1991. 361 p.

TAKAU JUNIOR, Iokisa. Escola itinerante: escola, Estado e MST no espaço do Acampamento. XIX Encontro Nacional De Geografia Agrária, São Paulo, 2009, Disponível

em http://www.geografia.fflch.usp.br/inferior/laboratorios/agraria/Anais\%20XIXENGA/artigo s/Takau-Jr_I.pdf Acesso em 22 de julho de 2011.

TAVARES, Maria Augusta. Os fios (in)visíveis da produção capitalista. Informalidade e precarização do trabalho. São Paulo: Cortez, 2004.

WEISSHEIMER, Marco Aurélio. Ministério Público e governo Yeda Crusius fecham escolas itinerantes do MST. 16/02/2009. Disponível em http://rsurgente.opsblog.org/2009/02/16/ministerio-publico-e-governo-yeda-crusiusfecham-escolas-itinerantes-do-mst/. Acesso em 01 de agosto de 2011.

\footnotetext{
${ }^{1}$ Escola localizada em acampamento, que pode mudar de lugar, portanto, que faz itinerância.

${ }^{2}$ Docente do Departamento de Pedagogia da Universidade Estadual do Centro Oeste, Guarapuava/PR; realizou a pesquisa como bolsista CNPq (2011-2013) ao realizar Doutorado em Educação (PPGE/UFSC/SC - 2010-2013).

${ }^{3}$ Silva (1971) indica que no Brasil esse processo de concentração é histórico e afirma que o índice Gini, que indica a concentração de terras, em 1920 era de 0,798; em 1940 de 0,826; em 1950 de 0,838 e, em 1960 era de 0,866 (índices considerados "forte a muito forte" numa escala que vai de 0 a 1,0 ).

${ }^{4} \mathrm{O}$ termo libertação foi cunhado a partir da realidade cultural, social, econômica e política sob a qual se encontrava a América Latina, a partir das décadas de 60/70 do século XX. Os teólogos deste período, católicos e protestantes, assumiram a libertação como paradigma de todo fazer teológico. (CABRAL, s/d, p. 2)

5 Segundo Pires (2001, p. 88) “Os sem-terra consideram como acampamentos, os agrupamentos de trabalhadores rurais que ocupam uma área ou se aglutinam em beiras de estradas, para a conquista da terra. Quando os ocupantes recebem um documento chamado "Imissão de Posse", assinado pelo governo, através do INCRA, a área passa a denominar-se assentamento”.
}

${ }^{6}$ Itaipu aceitou pagar $50 \%$ de indenização aos não-proprietários e pagamento das benfeitorias; aumentou o preço por hectare de terra; assumiu o compromisso de reajustá-lo automaticamente caso as indenizações demorassem a sair e de classificar a maior parte das terras dos imóveis como de primeira qualidade. Concordou ainda com as indenizações das redes elétricas e com outras reivindicações mais vinculadas à operacionalização dos pagamentos e das saídas dos lavradores da região. Além disso, os agricultores conseguiram dois assentamentos no Paraná - em Arapoti (para 400 famílias) e Toledo (para 20 famílias). (SERRA, 1991, . 297)

${ }^{7}$ Primeiro, nomeada como Comissão da Terra, posteriormente acrescentou-se 'pastoral' para descartar a possibilidade de parecer um Partido ou Sindicato (PIRES, 2001).

${ }^{8}$ No processo de luta, o MST criou muitos símbolos, hino e muitos lemas e gritos de ordem. Dois dos símbolos mais importantes são: a bandeira do Movimento, que foi aprovada no $3^{\circ}$. Encontro Nacional (em 1987) e o hino, aprovado no II Congresso, em Brasília (1990).

${ }^{9}$ No período de 2000 a 2006 o MST atuou no Paraná e em outros estados brasileiros (AL, BA, CE, DF, ES, GO, MA, MG, MS, MT, PA, PB, PE, PI, RJ, RN, RO, RR, RS, SC, SE, SP, TO). E essa não é uma luta isolada do MST. Além dele, no Paraná, nesse período também atuaram no processo de luta pela terra outros movimentos: CONTAG (Confederação Nacional dos Trabalhadores na Agricultura), Grupo Xambre, MAST (Movimento do Agricultores Sem Terra), MSO (Movimento Social Organizado), MSONT (Movimento Sonho da Terra), MSST (Movimento Social dos Sem Terra), MTB (Movimento dos Trabalhadores Rurais do Brasil), Quilombolas, OTC (Organização dos Trabalhadores no Campo), OAC (Organização Agrária Camponesa), MUT (Movimento Unidos pela Terra), MTR (Movimento dos Trabalhadores Rurais), MTRSTP (Movimento dos Trabalhadores Rurais Sem Terra do Paraná) (DATALUTA, 2006). 
10 Também em 01/09/2007, seiscentos Sem Terra ocupavam a Fazenda Alice, localizada entre Cornélio Procópio e Nova Fátima, da qual cerca de 200 alqueires não tinham documentação (FETEC/CUT, 2012).

${ }^{11}$ Entrevista concedida à autora em 12/04/2012.

12 Entrevista concedida à autora em 10/04/1012.

${ }^{13}$ Entrevista concedida à autora em 29/03/2012.

${ }^{14}$ Ver Gehrke (2010).

${ }^{15}$ Entrevista concedida à autora em 29/03/2012.

${ }^{16}$ Entrevista concedida à autora em 23/05/2012.

${ }^{17}$ Informações coletadas nos arquivos da Secretaria do MST, em Curitiba, em março de 2012.

${ }^{18}$ Entrevista concedida à autora em 29/03/2012.

${ }^{19} \mathrm{O}$ processo de reafirmação das questões prioritárias das escolas itinerantes foi registrado no Manifesto dos Educadores e Educadoras no II Seminário Nacional das Escolas Itinerantes dos Acampamentos do MST.

${ }^{20}$ Despejados três vezes em 2006; em 2009 houve a presença de milícias armadas que atacaram o acampamento.

${ }^{21}$ Num comparativo de custos entre produção mecanizada e manual, Giglioti e Cataneo (2009) chegaram às seguintes conclusões: na produção de cana (em uma Usina de Açúcar e Álcool na região do Bariri/SP) o custo da tonelada no corte manual era de R $\$ 6,92$; no corte manual terceirizado era de $\mathrm{R} \$ 8,14$ e no corte mecanizado de $\mathrm{R} \$ 5,04$, ou seja, $27,17 \%$ a menos em relação ao corte manual e $32 \%$ a menos em relação ao corte manual terceirizado; na compra de uma colhedora de $\mathrm{R} \$ 700.000,00$ que substitui 103,59 trabalhadores, considera-se: cada cortador ganha em média 647,00 por mês. Há 3 turnos de trabalho e 8 horas. O salário do operador de máquina colhedora era em 2005, R\$ 1600,00. Logo, 103,59 x R\$ 647,00= R\$ 67.022,73; mais a manutenção da máquina $\mathrm{R} \$ 8,500,00$; mais a força-de-trabalho de três operadores que são $\mathrm{R} \$ 4.800,00$ por mês, totalizando um custo mensal de $\mathrm{R} \$ 80.322,73$. Portanto, para adquirir a máquina o valor corresponde ao custo de 8,71 meses. Se a safra vai de março a dezembro, portanto 10 meses, o custo da máquina se cobre em apenas uma safra, dispensando 103,59 trabalhadores.

22 Entrevista concedida à autora em 29/03/2012.

${ }^{23} \mathrm{O}$ valor total desse Convênio era de R \$ 1.804.165,00 destinado ao pagamento dos educadores da Educação Infantil e dos anos iniciais do Ensino Fundamental, coordenadores das escolas, auxiliar de serviços gerais e merendeira.

${ }^{24}$ Entrevista concedida à autora em 10/04/2012.

${ }^{25}$ Entrevista concedida à autora em 10/04/2012.

${ }^{26}$ No II Seminário Nacional das Escolas Itinerantes, no Manifesto dos Educadores e Educadoras estão registradas dez razões pelas quais a EI se legitima e ganha importância para o MST.

${ }^{27}$ Entrevista concedida à autora em 05/07/2011.

Recebido: $\quad$ fevereiro-14 Aprovado: $\quad$ setembro-14 